\title{
〜第2報 呼吸位相補正法について〜
}

Basic Study of Superimpose to SPECT and CT images

(2nd Report : Correcting inconsistent depth of respiration)

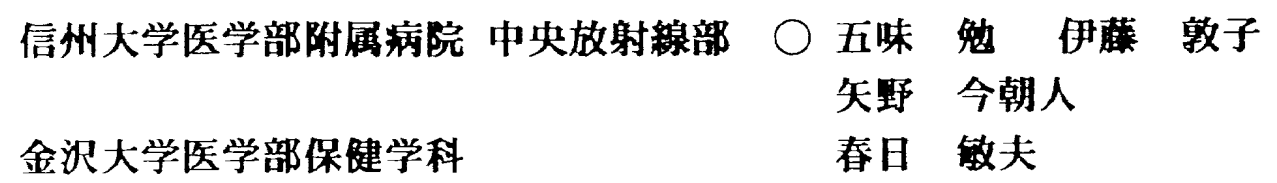

【目的】第52回総会時においで2017胸部SPECT像とCT像を重ね合わせる際,問題となる呼吸位相差を補正する 方法を考案しその有用性について報告した。今回新たに健常者から算出された肺の伸䊉度から回曼式を求め補 正対象となる仪:汭の位相を補正する简易的且つ重站合わせ誤差の少ない補正法を考案した。この䋠正法での

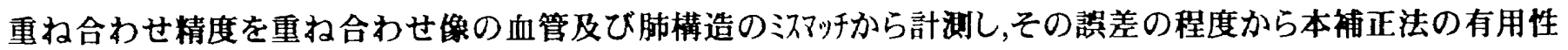
についての評価並びに基碳的検討を行った。

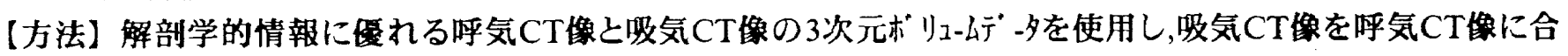
わせるような回帰補正式を下記1〜3の方法より算出した。

1)肺の伸縮度を調べるために5名の健常者を対象にして呼気CTと吸気CTの术リ1-4デ -夕を撮影した。

2)呼気CTと吸気CTで血管等の構造物の体軸方向の位置入゙ レを測定しX軸に呼気CTの位相,Y糨に吸気CTの位 相を定義してプ哆しそのグうから呼気CTに吸気CTを合わせるような回掃式を求めた(Fig. I )。

3)この回㿭式を用いて補正対象西像(今回の評価では吸気CT像, 実際のCTとSPECTの重ね合わせではSPECT 像)を基準面像(今回の評価では呼気CT像,実際のCTとSPECTの重ね合わせでは吸気CT像)に合わせるように 体軽方向に圧稀補正した。

上記1〜3の過程から求めた回帰式より呼気CT像の位相に補正された吸気CT像と呼気CT像を重ね合わせ,血管 等の構造物を指標に證差がごの程度になるかを調べた。尚,重ね合わせ操作の7゙虽不を以下に示す。

a)MPR上で3次元的に位置を確認しながらMid-Sagittal面に以下37亿多設定する(Fig.II)。

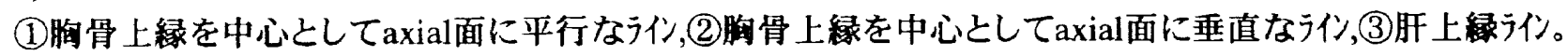

b)二つの画像の胸骨上縁う们を一致させるように重ね合わせて3ライイの位置川゚うれ-タを保存。ここで生じる肝上縁うイ ンの差を一致させるように先に求めた回帰式を参照にして補正対象画像の术りエ-Lデ -夕を圧㝘し再構成し直す。

【結果】Fig.IIIに基準西像(呼気CT)と補正西像(㖟気CT)の任意肺血管を指標とした胸骨上縁からの距離関係 を示す。一部の例外(case4,5)を除いて直線性が良くなっていることが示された。この補正回曼式を使用した重 ね合わせ誴差はFig.IIIより平均して約 $1 \mathrm{Cm}$ であり,上・中肺野部では良好で肺底部付近では潩差が大きくなる 傾向にあった。

【考察】今回考案した回帰式を体粙方向での位相補正に使用した結果, 重ね合わせ誤差は平均して約 $1 \mathrm{Cm}$ 以下 であり良好な効果を得た。ただ肺底部付近では複雜な肺の伸綰度が起因しているためか重ね合わせ誤差は大 きくなる傾向にあった。铻床的有用性としてはSPECTの空間分解能が13mmであり平静呼吸下でのSPECT像を

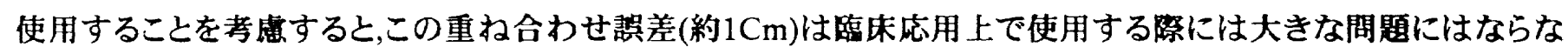
いと考える。

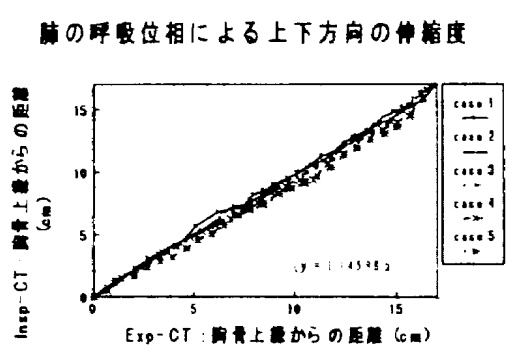

(Fig. I )

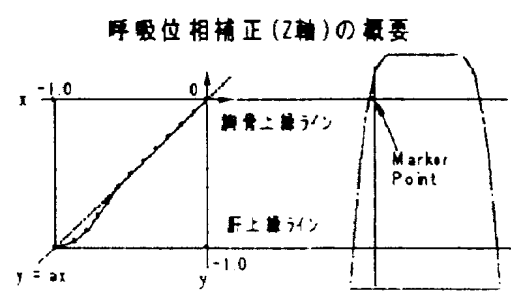

(Fig. II)

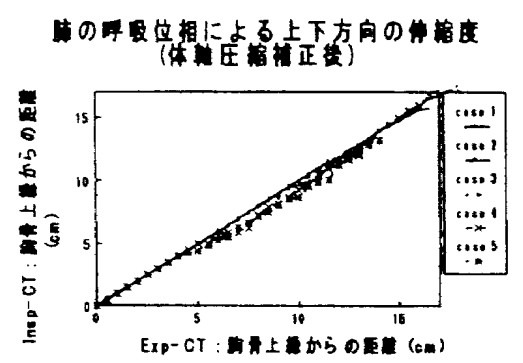

(Fig.III) 